\title{
Methylene Blue Removal from Aqueous Solution by Adsorption on Archidendron jiringa Seed Shells
}

\author{
Sarah Nadira Hurairah, Nurulhuda Md Lajis, Azhar Abdul Halim* \\ Department of Environmental Science \& Natural Resources, Faculty of Science and Technology, Universiti Kebangsaan Malaysia, \\ Bangi, Selangor, Malaysia \\ Email: *azharhalim@ukm.edu.my
}

How to cite this paper: Hurairah, S. N., Lajis, N. M., \& Halim, A. A. (2020). Methylene Blue Removal from Aqueous Solution by Adsorption on Archidendron jiringa Seed Shells. Journal of Geoscience and Environment Protection, 8, 128-143.

https://doi.org/10.4236/gep.2020.82009

Received: December 10, 2019

Accepted: February 17, 2020

Published: February 20, 2020

Copyright ( 2020 by author(s) and Scientific Research Publishing Inc. This work is licensed under the Creative Commons Attribution International License (CC BY 4.0).

http://creativecommons.org/licenses/by/4.0/

\begin{abstract}
A study of batch and column adsorption using $A$. jiringa seed shell as a natural adsorbent to remove methylene blue from aqueous solution was carried out. This study aimed to determine the effectiveness of $A$. jiringa seed shell in removing methylene blue as well as to determine the isotherm and adsorption kinetics of methylene blue by $A$. jiringa seed shells. Parameters in the batch study showed optimum $\mathrm{pH}$ for adsorption was at $\mathrm{pH} 7$ with the optimum contact time of 60 minutes whereas the adsorbent dose obtained was $12 \mathrm{~g} / \mathrm{l}$. The percentage removal of methylene blue increased with elevated temperature while the ionic strength reduced the adsorption capacity in the dye uptake. Langmuir isotherm was suitable for this study rather than Freundlich model due to the higher regression value: $R^{2}=0.9999$. The most suitable kinetic model for this study was the pseudo second order, compared to pseudo first order, Elovich and intra particle with the value of regression: $\mathrm{R}^{2}=0.9158$. This column adsorption study used several different flow rates: $15 \mathrm{~mL} / \mathrm{min}$, $18 \mathrm{~mL} / \mathrm{min}, 21 \mathrm{~mL} / \mathrm{min}, 24 \mathrm{~mL} / \mathrm{min}$ and $27 \mathrm{~mL} / \mathrm{min}$ for 75 minutes long. The breakthrough time was lesser: 10 minutes in higher flow rates $(24 \mathrm{~mL} / \mathrm{min}$ and $27 \mathrm{~mL} / \mathrm{min}$ ), which indicated the shorter time for the adsorbent to be saturated. Thomas and Yoon \& Nelson's models were proven to be more suitable compared to Bohart-Adams model for the fixed bed adsorption study.
\end{abstract}

\section{Keywords}

A. jiringa Seed Shells, Adsorption, Isotherm, Kinetic Model, Methylene Blue

\section{Introduction}

Numerous pollution issues had been brought upon by the industry sectors, and 
the biggest concern came from the industrial effluent emissions (Khan et al., 2005). More precisely, dye was one of the pollutants that had frequently contributed towards environmental pollution. A few industries which commonly used dye had included shell's materials, papers, textiles, printings, cosmetics (Lei et al., 2013), food products (Alzaydien, 2009), rubbers and plastics (Kanawade \& Gaikwad, 2011). The largest usage of dye came from textile industries (Gottipati \& Mishra, 2010) while the total usage of dye in the world was identified to be more than $107 \mathrm{~kg} /$ year (Mulugeta \& Lelisa, 2014). The textile industry played a significant role in the developing countries (Fatiha \& Belkacem, 2016).

Methylene blue was often used in the textile industry to dye cottons, wools and silks (Shahryari et al., 2010). The dye waste had often been found in the effluents released either in low or high concentrations (Lei et al., 2013). The disposal of pollutants must be taken care of seriously as it can affect the environment and cause adverse toxicological effects (Kanawade \& Gaikwad, 2011). Dye in wastewater contained dye compounds, which were originated from dye wastes and other chemical additives (Fatiha \& Belkacem, 2016). Any dye effluents introduced into the river or water system will disrupt the biological activities and aquatic ecosystem (Sodeinde \& Eboreime, 2013). The dye compounds might trigger ecological problems such as chemical oxygen demand (COD), increased level of toxins in the water and deterred penetration of sunlight into the water bodies, which all of them will subsequently harm the underground water through leaching process from the land (soil). Apart from that, the use of dyes could lead to bioaccumulation, which can interrupt the human food chain (Shehata, 2013) and consequently, cause detrimental effects to the human health (Mohammed et al., 2014).

Dye effluents were harder to be treated due to their synthetic properties, especially the aromatic structures that were not able to disintegrate biologically (Mohammed et al., 2014). There were many types of methods usually used in solving this pollution issue namely flocculation, oxidation processes, ozonation processes, electrochemical techniques as well as adsorption (Oyelude \& Appiah-Takyi, 2012). However, physical adsorption was the best method in removing dye by-products from the industrial wastewater (Tsai et al., 2009). Wastewater containing dyes could produce damaging effects to the environment and human health. Methylene blue dyes were the source to health problems such as gastrointestinal tract irritation, nausea symptoms, vomiting and diarrhoea (Al Husseiny, 2014). Moreover, in this research, the lower-cost adsorbent that can serve as an alternative was studied in order to obtain the most suitable and effective natural adsorbent in the removal of methylene dye from wastewater. The adsorbent material must have high adsorbent characteristics, potentially capable in ion exchange, cheap and easily available (Suteu \& Malatan, 2013).

Previous studies focusing on batch adsorption of $\mathrm{Cu}(\mathrm{II})$ ions by using Pithecellobium jiringa shells were done by other researchers with ultrasonic assistance. In a different study, Pithecellobium jiringa seed shell waste was used in producing activated carbon to adsorb $\mathrm{Cu}$ (II) ions from aqueous solution (Mus- 
lim A., Ellysa, E., \& Said S. D., 2017) which indicated its applicability in removing toxic heavy metals as well. The research conducted involved FTIR and SEM analyses as well as kinetic isotherms such as Freundlich, Langmuir and pseudo second order kinetic order. This research, on the other hand, mainly involved the removal of methylene blue as the pollutant. Besides that, this research aims to find an alternative method for the usage of activated carbon, which was costly to be used commercially for the organic compounds (Velmurugan et al., 2011). Therefore, the more cost-effective and widely abundant agricultural waste was investigated for its potentials such as banana peels (Moubarak et al., 2014), sugarcane bagasse, coconut husks, paddy husks and (Mathivanan \& Saranathan, 2015), lime shells, Neem leaves (Velmurugan et al., 2011), barley, rice husk and wood dust (Al Husseiny, 2014). This research was conducted by using Pithecellobium jiringa due to its absence in economic values. $A$. jiringa was one of the fruits that can be abundantly found in Southeast Asia's countries such as Malaysia, Thailand and Indonesia.

The objective of this study was to determine the effectiveness of $A$. jiringa seed shells as the adsorbent material in removing methylene blue from aqueous solution as well as to determine the adsorption kinetics and isotherm onto the $A$. $j i$ ringa seed shells.

\section{Materials and Methods}

The first part involved the preparation of materials such as methylene blue stock solution and adsorbent material. The second part included the adsorption processes: batch adsorption and column adsorption. Thirdly, the determination of concentration of methylene blue adsorbed was carried out. Lastly, data analysis in determining the capacity of adsorption by using a few models was performed.

Natural adsorbents used were $A$. jiringa seed shells. Chemical substances used were analytical graded hydrochloric acid, natrium hydroxide, methylene blue (MERCK) and plumbum chloride. Apparatuses used were orbital shaker model 720-D (PROTECH), pH meter (Trans Instrument), spectrophotometer (DR/2700 HACH), peristaltic pump (Longer Pump), conical flask (PYREX), electronic balance (Mettler TOLEDO), blender (Panasonic). Stirring hotplate model HS0707V2 (FAVORIT) and filtration vacuum pump model 600 (Rocker).

\subsection{Preparation of Adsorbent}

$A$. jiringa seed shells which had been transformed into smaller pieces had been dried in a drying oven. Next, $A$. jiringa seed shells had been ground as a finer form and washed by using distilled water to remove any dirt. It was then dried at $100^{\circ} \mathrm{C}$ for 24 hours before the filtration process to obtain particles of $5 \mathrm{~mm}$ size or lesser.

\subsection{Preparation of Methylene Blue Solution}

$1.0 \mathrm{~g}$ of methylene blue was weighed with electronic balance and transferred into 
a $100 \mathrm{~mL}$ volumetric flask. Methylene powder was dissolved using distilled water in the volumetric flask and filled up until calibration level. Methylene blue stock solution was diluted by a few dilution factors: one, two, three, four, five and six ppm. $0.1 \mathrm{~mL}$ stock solution was pipetted and inserted into a $100 \mathrm{~mL}$ volumetric flask till the calibration level to obtain $1 \mathrm{ppm}$ methylene blue solution. Steps were repeated to produce the rest of the other concentrations, where $0.2 \mathrm{~mL}$ was taken to produce $2 \mathrm{ppm}, 0.3 \mathrm{~mL}$ for $3 \mathrm{ppm}, 0.4 \mathrm{~mL}$ for $4 \mathrm{ppm}, 0.5 \mathrm{~mL}$ for $5 \mathrm{ppm}$ and $0.6 \mathrm{~mL}$ for $6 \mathrm{ppm}$. The adsorption of diluted solution was determined using spectrophotometer DR/2700 at wavelength $665 \mathrm{~nm}$.

\subsection{Batch Adsorption Study}

$1.0 \mathrm{~g}$ of adsorbent was inserted into $50 \mathrm{~mL}$ methylene blue solution in a parafilm covered conical flask to avoid evaporation. The conical flask series were placed on an orbital shaker for two hours at $200 \mathrm{rpm}$. The shaker helped to ensure equal adsorption. Then, the mixture was filtered manually by using microfiber filter paper to obtain the filtrate. The products were then filtered and analyzed by using Spectrophotometer DR/2700 to obtain the final concentration of methylene blue solution. Optimum $\mathrm{pH}$ determined the rate of methylene blue removed in the solution. The $\mathrm{pH}$ of methylene blue was standardized from $\mathrm{pH} 4$ until $\mathrm{pH} 10$ by using hydrochloric acid (HCL) and natrium hydroxide $(\mathrm{NaOH})$ solutions. Optimum $\mathrm{pH}$ was determined by analyzing the highest rate of removal of methylene blue from the filtrate in the filtration process.

Optimum contact time was studied where conical flasks were set up with interval times: 5 minutes, 10 minutes, 15 minutes, 30 minutes, 60 minutes and 120 minutes. Methylene blue solution was prepared according to optimum $\mathrm{pH}$ obtained before the input of absorbent. The conical flasks were shaken and put aside at the fixed interval times. The conical flasks were filtered manually to obtain the specified parallel interval times. The optimum contact time was determined when there were no changes in the concentration of methylene blue after equilibrium time had been achieved.

In the adsorbent dose study, a few conical flasks containing $50 \mathrm{~mL}$ methylene blue solution were prepared and a few different adsorbent masses, specifically $0.1 \mathrm{~g}, 0.2 \mathrm{~g}, 0.3 \mathrm{~g}, 0.4 \mathrm{~g}, 0.5 \mathrm{~g}, 0.6 \mathrm{~g}, 0.7 \mathrm{~g}$ and $0.8 \mathrm{~g}$ were placed in each conical flask. Every conical flask series was standardized to the optimum $\mathrm{pH}$ and shaken according to optimum contact time obtained. The solution was filtered manually before the filtered yield was analyzed to determine the rate of methylene blue removed.

The adsorption isotherm study was derived from adsorbent dose study. Langmuir and Freundlich models were the models used in adsorption isotherm study. In this study, linear line graphs were plotted by using these two models. $\mathrm{R}^{2}$ constant values obtained from both models were then compared to represent the models in the adsorption isotherm study. Adsorption kinetic study by using equilibrium time obtained from contact time was conducted. Analyzed data acquired from methylene blue solutions was processed by using four adsorption kinetics equa- 
tions, specifically pseudo first-order kinetic model, pseudo second-order kinetic model, Elovich model and intra-particle kinetic model. $\mathrm{R}^{2}$ values for the models were compared to obtain the highest value to represent the adsorption kinetic model for this study.

\subsection{Effect of Temperature}

$0.1 \mathrm{~g}$ of methylene blue powder was weighed by using electronic balance and inserted into a $100 \mathrm{~mL}$ volumetric flask. Distilled water was added until graduation level. Methylene blue stock solution of $1000 \mathrm{mg} / \mathrm{L}$ was produced. In preparing a $10 \mathrm{mg} / \mathrm{L}$ methylene blue stock solution, $10 \mathrm{~mL}$ of methylene blue solution was obtained from the stock solution and transferred into a $1.0 \mathrm{~L}$ volumetric flask. 50 $\mathrm{mL}$ of diluted methylene blue solutions was inserted into a $50 \mathrm{~mL}$ conical flask.

$0.1 \mathrm{~g}$ of $A$. jiringa seed shell extract was weighed by using an electronic balance and placed into the flask. The flask was placed on a stirring hotplate and set at temperature: $25^{\circ} \mathrm{C}$. The solution was stirred to allow equal adsorption for 20 minutes. The solution was then filtered using a filtration vacuum pump. Filtrate obtained was analysed by using Spectrophotometer DR/2700 to obtain the final concentration of methylene blue solution. Experiments were repeated at varied temperatures: $40^{\circ} \mathrm{C}, 65^{\circ} \mathrm{C}$ and $75^{\circ} \mathrm{C}$.

\subsection{Effect of Ionic Strength}

Potassium chloride powder was weighed by using an electronic balance to prepare solutions of different ionic strengths: $1.0 \mathrm{M}, 0.5 \mathrm{M}, 0.1 \mathrm{M}$ and $0.05 \mathrm{M}$. The salt powder was then transferred into four $100 \mathrm{~mL}$ conical flasks filled with 50 $\mathrm{mL}$ methylene blue solution of $10 \mathrm{ppm}$ concentration. The flasks were stirred and shaken slightly for 20 minutes to allow equal distribution of salt and an enhanced adsorption process. Later, the solutions were filtered by using a filtration vacuum pump. The filtrates obtained were analyzed by using spectrophotometer $\mathrm{DR} / 2700$ to obtain the final concentration of methylene blue solution.

\subsection{Column Adsorption Study}

$20 \mathrm{~g}$ of $A$. jiringa seed shells was weighed and inserted before placing it in the column. Methylene blue solution was flowed by using the peristaltic pump to create pressure. This is to ensure that methylene blue can flow from the bottom to upwards through the absorbent. Single column adsorption was conducted for 75 minutes, and the filtrate was taken at each 5-minute interval.

As for the adsorption at different flow rates, $20 \mathrm{~g} \mathrm{~A}$. jiringa seed shells was weighed by using the electronic balance and inserted into the column. Distilled water was flowed to remove the excess dirt from $A$. jiringa seed shells. After the stored water turned clear, methylene blue stock was flowed through the column at flow rate of $15 \mathrm{~mL} / \mathrm{min}, 18 \mathrm{~mL} / \mathrm{min}, 21 \mathrm{~mL} / \mathrm{min}, 24 \mathrm{~mL} / \mathrm{min}$ and $27 \mathrm{~mL} / \mathrm{min}$ by using a peristaltic pump for 75 minutes. The methylene blue solution was taken at fixed 5-minute interval time whereas the value of the final concentration of the solution was analyzed by using Spectrophotometer DR/2700. Tho- 
mas, Yoon and Nelson and Bohart-Adams models were used to determine the capacity of adsorption of methylene blue and to represent the adsorption. A linear graph was plotted to obtain $\mathrm{R}^{2}$ value while the value at the intercept point referred to the value of adsorption capacity, $q_{0}$. Methylene blue concentration was analyzed using Spectrophotometer DR/2700 at wavelength of $665 \mathrm{~nm}$.

\section{Results and Discussion}

\section{Batch Adsorption Study}

\section{Effect of $\mathrm{pH}$}

The optimum $\mathrm{pH}$ obtained in this batch adsorption study was $\mathrm{pH} 7$ (98.82\%) as shown in Figure 1. However, there was no significant changes between $\mathrm{pH} 4$ until $\mathrm{pH}$ 8. The percentage of dye removed increased for the adsorption of cationic dye at high $\mathrm{pH}$ due to excess presence of $\mathrm{H}+$, which competed with cation groups in dye for adsorption (Bharathi \& Ramesh, 2013). With an increased $\mathrm{pH}$ of solution, the electrostatic attraction between positive charges of cationic dyes with the surface of adsorbent became low thus this increased the potential of dye removal (Ansari \& Mosayebzadeh, 2010). According to Pamukoglu et al. (2017), the adsorption capacity was minimum at $\mathrm{pH} 2$ and increased until $\mathrm{pH} 4$, then continued until there were almost no changes between $\mathrm{pH} 4$ and pH 10.

\section{Effect of Contact Time}

The adsorption capacity for adsorbate increased with an increase in contact time (Halim A. A. et al., 2012). The interval time was set with the similar amount of adsorbent: one $\mathrm{g}$ at $\mathrm{pH}$ 7, which was the optimum $\mathrm{pH}$ obtained. After 60 minutes, the removal of dye stayed at $98.12 \%$ as shown in Figure 2. The removal rate of dye increased with contact time until a certain time when contact time did not affect the dye removal anymore due to settlement of dye on the surface of adsorbent (Ansari \& Mosayebzadeh, 2010).

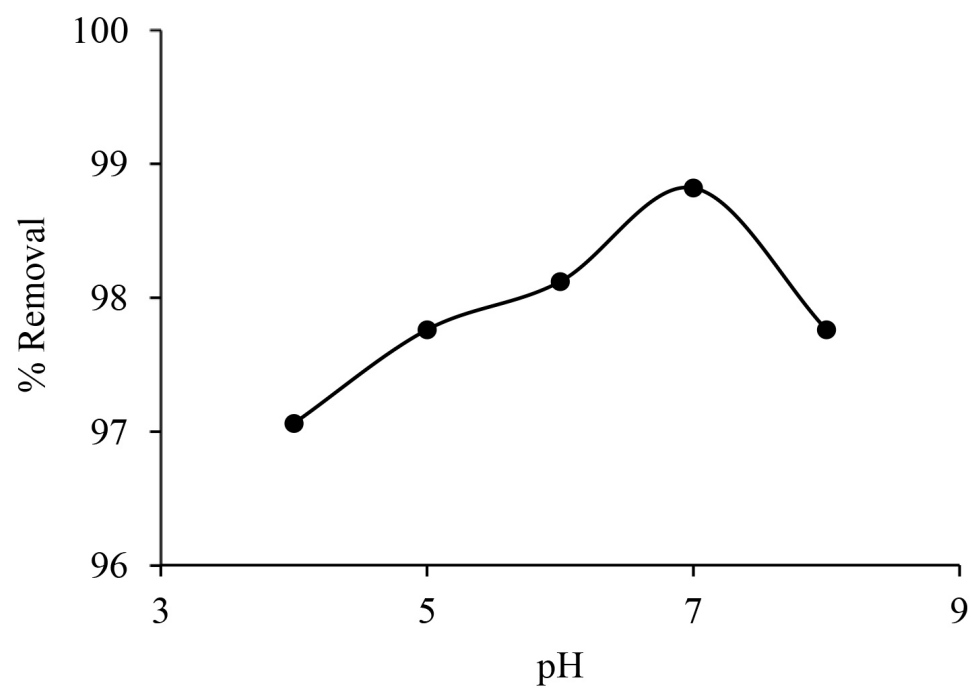

Figure 1. Effect of $\mathrm{pH}$ on methylene blue removal using $A$. jiringa seed shells as adsorbents. 


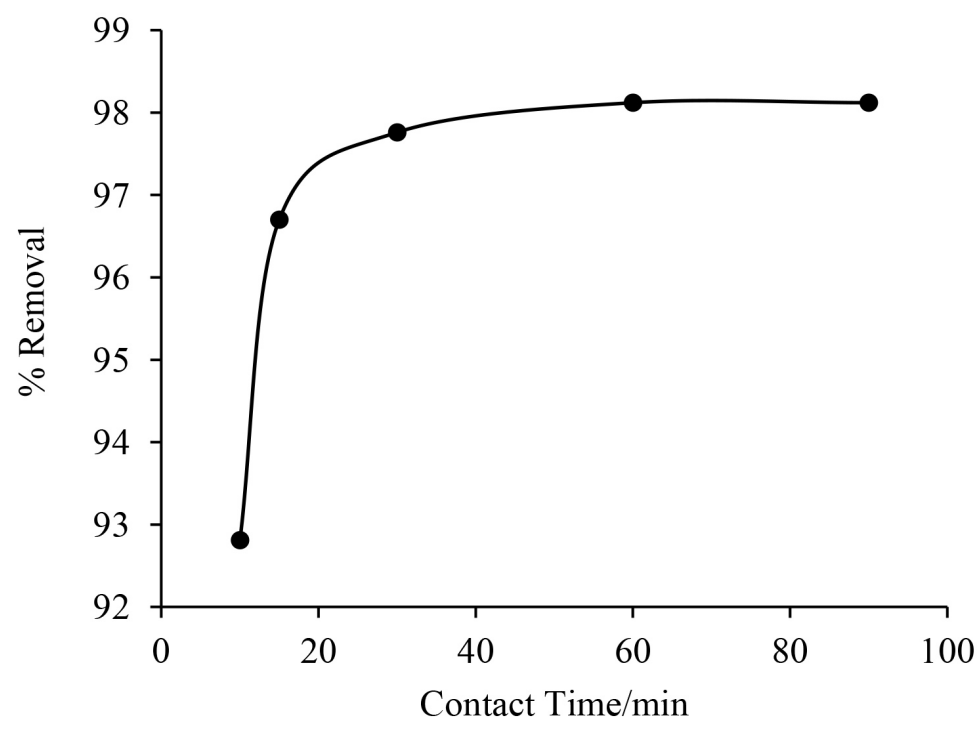

Figure 2. Effect of contact time on methylene blue removal using $A$. jiringa seed shells as adsorbents.

\section{Effect of Adsorbent Dose}

As shown in Figure 3, the removal of methylene blue increased logarithmically. The percentage of removal was found out to have increased with an increase in the adsorbent dose (Dharmendra \& Rasma, 2015). The removal of dye through adsorption was found to have been increasing alongside dose of adsorbent (Halim, A. A., Kee, K. H., \& Hanafiah, M. M., 2015). This was due to increased surface area of adsorbent (Goswami et al., 2014; Patil et al., 2011). However, upon reaching a certain dose, the percentage of removal was no longer affected due to dye becoming easier to interact with surface of adsorbent at a lower dose (Bharathi \& Ramesh, 2013). The particles of adsorbent might overlap with each other and hindered the interaction between adsorbent surface and dye molecules which caused no changes in the rate of dye removed (Dutta et al., 2011).

\section{Effect of Temperature}

As shown in Figure 4, the percentage removal of methylene blue increased with elevated temperature $\left(25^{\circ} \mathrm{C}-75^{\circ} \mathrm{C}\right)$. An increase in temperature lead to an increase in the amount of dye sorbed. At $18^{\circ} \mathrm{C}, 9.71 \mathrm{ppm}$ of dye was sorbed whereas at $75^{\circ} \mathrm{C}, 9.77 \mathrm{ppm}$ of dye was removed. According to H. Benaïssa (2009), temperature mainly affected the adsorption of methylene blue which increased as the temperature increased. In the study, spontaneous and endothermic progresses were shown by the thermodynamic parameters obtained.

\section{Effect of Ionic Strength}

Dye removal was identified to be greatly affected by ionic concentrations introduced (R. Slimani et al., 2011). Figure 5 showed results whereby an increase of $\mathrm{PbCl}$ salt caused a decrease in dye uptake. At $0.05 \mathrm{M}$ ionic strength, the percentage of dye removed was $99.9 \%$ while at greater salt concentration $(1.0 \mathrm{M})$, dye uptake reached up to only $99.5 \%$. 


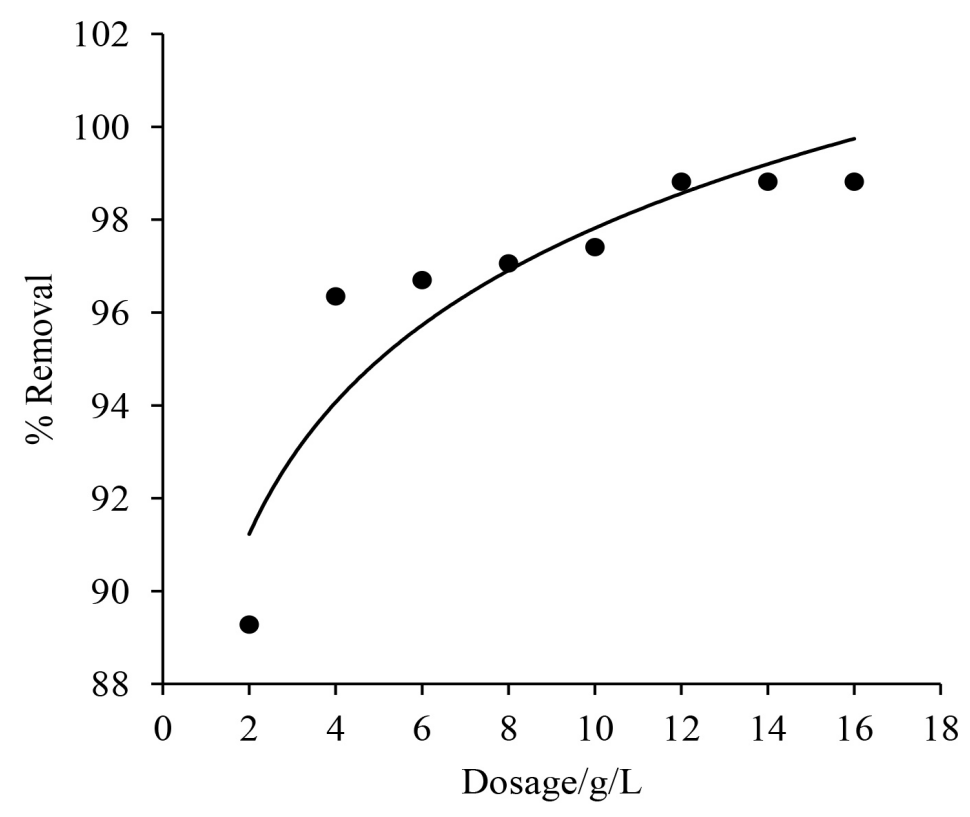

Figure 3. Effect of $A$. jiringa seed shells dosage on methylene blue removal.

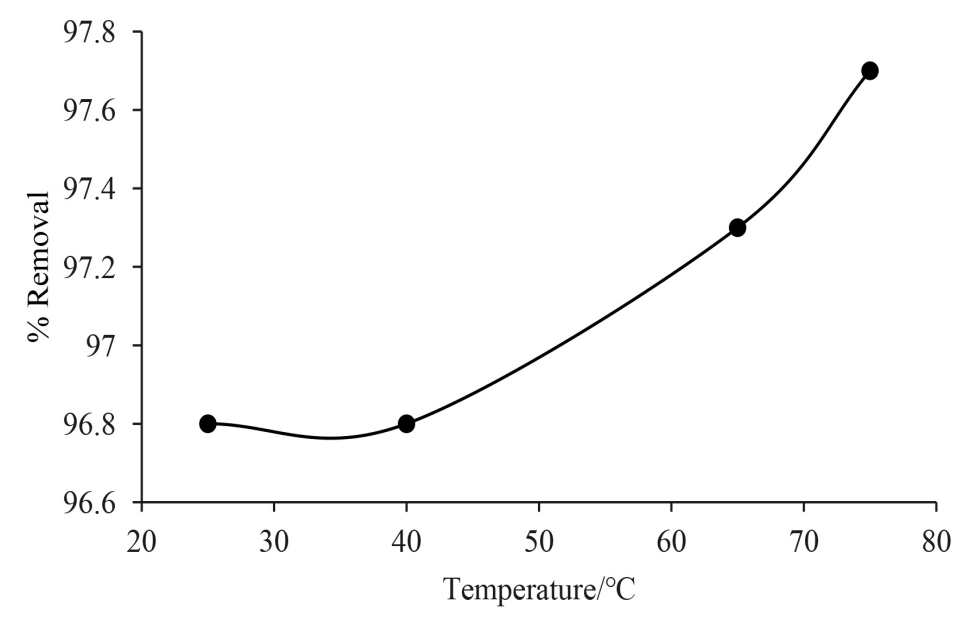

Figure 4. Effect of temperature on methylene blue removal using $A$. jiringa seed shells as adsorbents.

This could be explained by the phenomenon whereby the surface of adsorbent was less accessible to the dye removal at a higher salt presence. Hence, sorption of methylene blue became lower (R. Slimani et al., 2011). Furthermore, when an adsorbent had met with an adsorbate in a solution, they will be enveloped by a double electric diffuse layer (Boumediene, M. et al., 2018). Salt hindered dye removal process which occurred on the adsorbent's surface. The positive attraction of electrostatic force was formed in between the adsorbent and adsorbate, thus, the adsorption capacity was reduced along with a rise in ionic strength (A. Habib et al., 2007).

\section{Adsorption Isotherm}

Adsorption isotherm described how the solution interacted with the adsorbent to optimize the use of adsorbent (Uddin et al., 2009). As shown in Table 1, both 


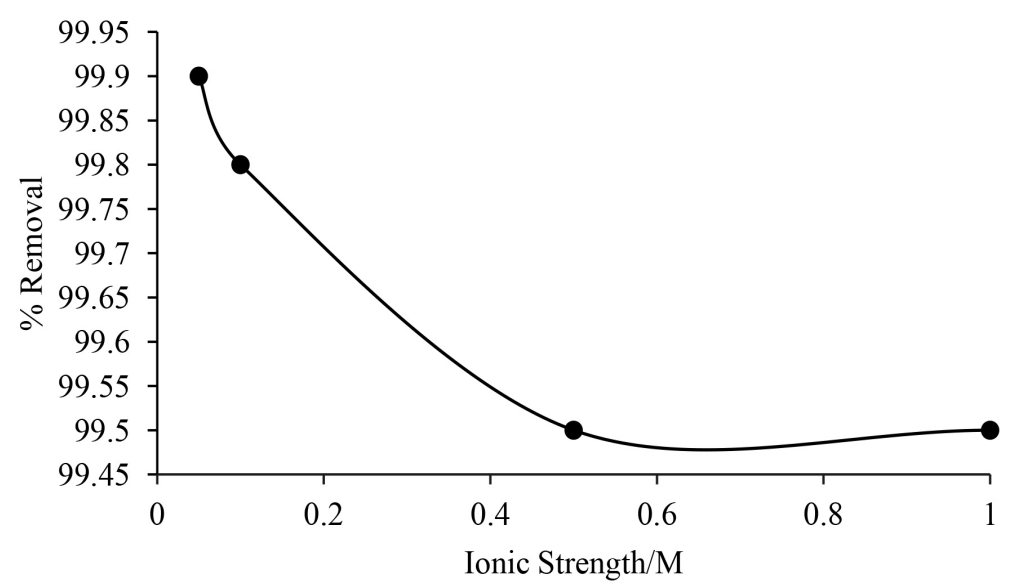

Figure 5. Effect of ionic strength on methylene blue removal using $A$. jiringa seed shells as adsorbents.

Table 1. Langmuir and freundlich constant values and $\mathrm{R}^{2}$.

\begin{tabular}{cc}
\hline Model & \\
\hline Langmuir & \\
\hline $\mathrm{q}_{\mathrm{m}}(\mathrm{mg} / \mathrm{g})$ & 44.6429 \\
$\mathrm{~K}_{\mathrm{L}}(\mathrm{L} / \mathrm{mg})$ & 0.0045 \\
$\mathrm{R}_{\mathrm{L}}$ & 0.1818 \\
$\mathrm{R}^{2}$ & 0.9999 \\
\hline Freundlich & \\
\hline $1 / \mathrm{n}$ & 0.1259 \\
$\mathrm{n}$ & 7.9428 \\
\hline $\mathrm{K}_{\mathrm{F}}\left((\mathrm{mg} / \mathrm{g})(\mathrm{mg} / \mathrm{L})^{\mathrm{n}}\right)$ & 1.0787 \\
$\mathrm{R}^{2}$ & 0.8667 \\
\hline
\end{tabular}

regression values had been compared, and Langmuir model had the highest $\mathrm{R}^{2}$ : 0.9999 compared to Freundlich model. Higher $\mathrm{R}^{2}$ indicated that adsorption of methylene blue towards the $A$. jiringa seed shells was more on the monolayer (Oladoja et al., 2008). Once the dye molecule filled up the base of adsorbent, adsorption did no longer occur at the base (Elass et al., 2010). In this study, Langmuir was more suitable due to its homogen distribution in the active sites of $A$. jiringa seed shells.

$\mathrm{R}_{\mathrm{L}}$ was important for the Langmuir isotherm model, and the value showed either no inclination $\left(R_{L}>1\right)$, linear $\left(R_{L}=1\right)$, inclination $\left(0<R_{L}<1\right)$ and unchanged $\left(\mathrm{R}_{\mathrm{L}}=10\right)$ (Azraa Achmad et al., 2012). $\mathrm{R}_{\mathrm{L}}$ obtained was in between 0 and 1 , which were 0.1818 that showed an inclination in methylene blue adsorption by $A$. jiringa seed shells.

\section{Adsorption Kinetics}

Adsorption kinetics was usually studied based on these kinetic models: pseudo 
kinetic first-order, pseudo kinetic second-order, Elovich model and intra-particle model (Halim, A. A. et al., 2011). The mechanism and rate of adsorption were studied by using a few different adsorption kinetics (Oladoja et al., 2008; Uddin et al., 2009). Regression value for pseudo second-order model showed the highest value: 0.9158 followed by pseudo first-order model with 0.8912 value and intra particle model and Elovich model with similar value, which was 0.7964 as shown in Table 2. The pseudo second-order model was the most suitable for this study, and this showed that the adsorption was controlled by chemical adsorption (Patil et al., 2011) which involved the exchange or sharing of electrons between dye and adsorbent (Priyantha et al., 2015).

\section{Fixed-Bed Column Adsorption Study}

Column study results were presented as breakthrough curves as shown in Figure 6. Flow rates $24 \mathrm{~mL} / \mathrm{min}$ and $27 \mathrm{~mL} / \mathrm{min}$ showed that breakthrough time decreased drastically in the $10^{\text {th }}$ minute. With increased flow rate, not all dissolved substance in the solution had enough time to react with adsorbent (Janet et al., 2015; Halim et al., 2010) which caused dissolved substance to leave the column faster (Sulyman, 2014). Lower flow rates, $15 \mathrm{~mL} / \mathrm{min}, 18 \mathrm{~mL} / \mathrm{min}$ and 21 $\mathrm{mL} / \mathrm{min}$ took longer times to breakthrough, which were 45 minutes, 40 minutes and 35 minutes. Time for adsorbent to be saturated increased with reduced flow rate (Al-Baidhany \& Al-Salihy, 2016). Table 3 explained the comparison between Thomas, Yoon and Nelson and Bohart-Adams fixed bed adsorption models, while Table 4 listed the Thomas, Yoon and Nelson and Bohart-Adams models parameters at different flow rates.

Table 2. Constant values and $\mathrm{R}^{2}$ for first-order pseudo, second-order pseudo, Elovich and intra particle models.

\begin{tabular}{|c|c|}
\hline Adsorption Kinetic Mo & \\
\hline \multicolumn{2}{|c|}{ First-order Pseudo } \\
\hline $\mathrm{K}_{1}\left(\min ^{-1}\right)$ & 2.4948 \\
\hline $\mathrm{q}_{\mathrm{e}}(\mathrm{mg} / \mathrm{g})$ & 0.009 \\
\hline $\mathrm{R}^{2}$ & 0.8912 \\
\hline \multicolumn{2}{|c|}{ Second-order Pseudo } \\
\hline $\mathrm{K}_{2}\left(\mathrm{~g} \cdot \mathrm{mmol}^{-1} \cdot \mathrm{min}^{-1}\right)$ & 25.1734 \\
\hline $\mathrm{q}_{\mathrm{e}}$ & 0.0251 \\
\hline $\mathrm{R}^{2}$ & 0.9158 \\
\hline \multicolumn{2}{|c|}{ Elovich } \\
\hline$\beta\left(\mathrm{g} \cdot \mathrm{mmol}^{-1}\right)$ & 185.1852 \\
\hline$\alpha\left(\mathrm{mol} \cdot \mathrm{g}^{-1} \cdot \mathrm{min}^{-1}\right)$ & $5.6491 \times 10^{34}$ \\
\hline $\mathrm{R}^{2}$ & 0.7964 \\
\hline \multicolumn{2}{|c|}{ Intra-particle } \\
\hline $\mathrm{C}$ & 0.4603 \\
\hline $\mathrm{K}_{\mathrm{t}}\left(\mathrm{mg} / \mathrm{g} \cdot \mathrm{min}^{-1 / 2}\right)$ & 0.0054 \\
\hline $\mathrm{R}^{2}$ & 0.7964 \\
\hline
\end{tabular}




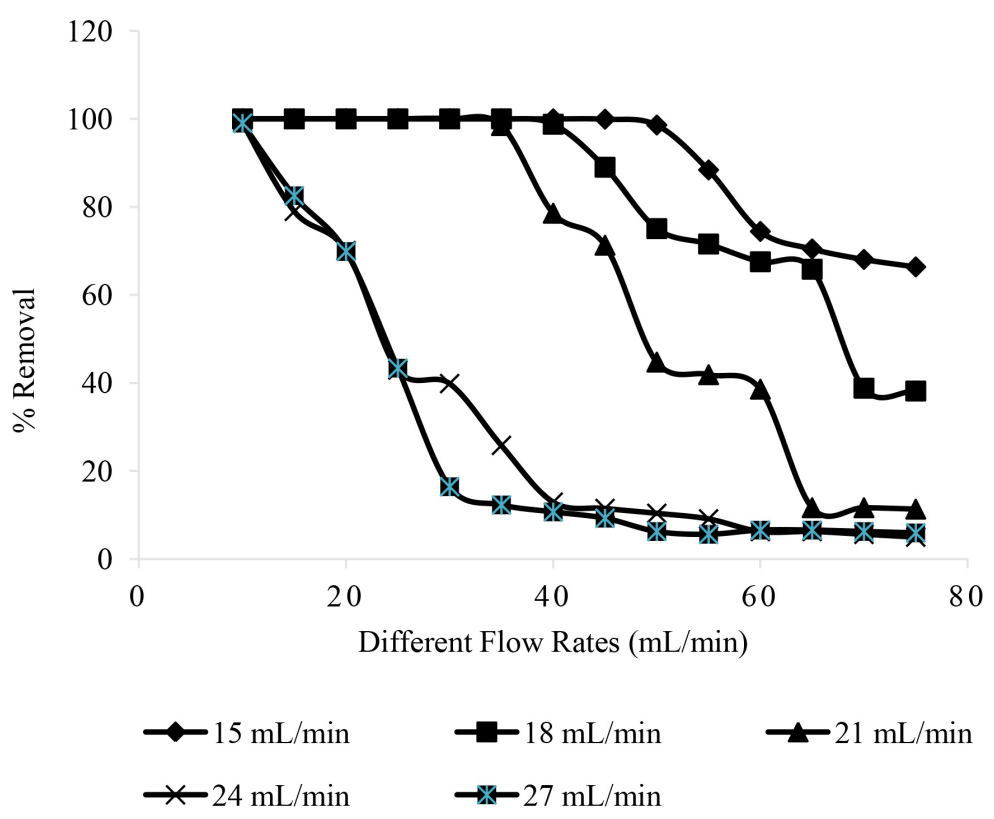

Figure 6. Percentage of removal in different flow rates.

Table 3. Comparison between Thomas, Yoon and Nelson and Bohart-Adams models.

\begin{tabular}{cl}
\hline $\begin{array}{c}\text { Fixed bed } \\
\text { adsorption models }\end{array}$ & \multicolumn{1}{c}{ Model prediction and explanation } \\
\hline & $\begin{array}{l}\text { Thomas's model predicted a dynamic adsorption which illustrated the future } \\
\text { performance of adsorption for the best design of column adsorption (Auta, } \\
\text { 2012). This model assumed that the distribution of axes was neglected in } \\
\text { column adsorption which defined Langmuir's concept (Aksu \& Gönen, }\end{array}$ \\
Thomas & $\begin{array}{l}\text { 2004). According to this model's plot, the capacity of adsorption at } \\
\text { Model }\end{array}$ \\
& $\begin{array}{l}\text { equilibrium, } \mathrm{q}_{\mathrm{o}} \text { decreased while the constant, } \mathrm{k}_{\mathrm{Th}} \text { increased with an increased } \\
\text { flow rate due to interaction time between solution and the limited adsorbent } \\
\text { in the column (Auta, 2012). The regression value, } \mathrm{R}^{2} \text { for this model was in } \\
\text { between } 0.7486 \text { and } 0.9527, \text { which indicated the suitability of column } \\
\text { adsorption study conducted. }\end{array}$
\end{tabular}

Yoon and Nelson model assumed the probability of adsorbent molecule adsorbed was proportional to the probability of the adsorption of adsorbate (Tamilselvi \& Asaithambi, 2015). The constant, $\mathrm{k}_{\mathrm{YN}}$ increased while $\mathrm{t}_{0.5}(\mathrm{~min})$,

Yoon and Nelson the breakthrough time needed for $50 \%$ of the materials to be adsorbed

Model decreased with an increased flow rate. Adsorbent became saturated in a shorter time at higher flow rate, which lead to a reduced value of $\mathrm{t}_{0.5}(\mathrm{~min})$ (Tamilselvi \& Asaithambi, 2015). The regression value, $\mathrm{R}^{2}$ for this model was in between 0.7486 and 0.9527 , which showed that the model was suitable for column adsorption study.

Adams Bohart model explained the beginning parts of the breakthrough time (Han et al., 2009). This model assumed that adsorption process was continuous, and equilibrium could not be reached immediately (Sekhula et al., 2012). Adams Bohart constant value, $\mathrm{k}_{\mathrm{AB}}$ increased with increased flow Bohart-Adams Model rate. This indicated that the whole kinetic system was controlled by the movement of outer mass at the beginning of column adsorption (Aksu \& Gonen, 2004). The range of regression value, $\mathrm{R}^{2}$ was lower than the others which lay in between 0.722 and 0.8383 . 
Table 4. Thomas, Yoon and Nelson and Bohart-Adams models parameters at different flow rates.

\begin{tabular}{|c|c|c|c|c|c|}
\hline \multirow{6}{*}{ Thomas Model } & $\mathrm{Q}(\mathrm{mL} / \mathrm{min})$ & $\mathrm{C}_{\mathrm{o}}(\mathrm{mg} / \mathrm{L})$ & $\mathrm{q}_{\mathrm{o}}(\mathrm{mg} / \mathrm{g})$ & $\mathrm{k}_{\mathrm{TH}}(\mathrm{mL} / \mathrm{minit} \cdot \mathrm{mg})$ & $\mathrm{R}^{2}$ \\
\hline & 15 & 1000 & 4.94 & $3.021 \times 10^{-4}$ & 0.7486 \\
\hline & 18 & 1000 & 4.2274 & $3.467 \times 10^{-4}$ & 0.8577 \\
\hline & 21 & 1000 & 3.4332 & $5.962 \times 10^{-4}$ & 0.9054 \\
\hline & 24 & 1000 & 2.5276 & $6.290 \times 10^{-4}$ & 0.9527 \\
\hline & 27 & 1000 & 2.2288 & $7.626 \times 10^{-4}$ & 0.8934 \\
\hline \multirow{6}{*}{$\begin{array}{l}\text { Yoon and Nelson } \\
\text { Model }\end{array}$} & $\mathrm{Q}(\mathrm{mL} / \mathrm{min})$ & $\mathrm{C}_{\mathrm{o}}(\mathrm{mg} / \mathrm{L})$ & $\mathrm{t}_{0.5}(\mathrm{~min})$ & $\mathrm{k}_{\mathrm{YN}}(\mathrm{L} / \mathrm{min})$ & $\mathrm{R}^{2}$ \\
\hline & 15 & 1000 & 6.5867 & 0.3012 & 0.7486 \\
\hline & 18 & 1000 & 4.6971 & 0.3467 & 0.8577 \\
\hline & 21 & 1000 & 3.2896 & 0.5926 & 0.9045 \\
\hline & 24 & 1000 & 2.1064 & 0.629 & 0.9527 \\
\hline & 27 & 1000 & 1.6509 & 0.7626 & 0.8934 \\
\hline \multirow{6}{*}{$\begin{array}{c}\text { Bohart- } \\
\text { Adams Model }\end{array}$} & $\mathrm{Q}(\mathrm{mL} / \mathrm{min})$ & $\mathrm{C}_{\mathrm{o}}(\mathrm{mg} / \mathrm{L})$ & $\begin{array}{c}\mathrm{k}_{\mathrm{AB}} \times 10^{-4} \\
(\mathrm{~L} / \mathrm{min} \cdot \mathrm{mg})\end{array}$ & $\mathrm{N}_{\mathrm{o}}(\mathrm{mg} / \mathrm{L})$ & $\mathrm{R}^{2}$ \\
\hline & 15 & 1000 & 2.349 & 8931.46 & 0.722 \\
\hline & 18 & 1000 & 7.513 & 6917.45 & 0.7533 \\
\hline & 21 & 1000 & 8.217 & 6960.472 & 0.7585 \\
\hline & 24 & 1000 & 9.469 & 7699.398 & 0.7324 \\
\hline & 27 & 1000 & 12.727 & 7378.487 & 0.8383 \\
\hline
\end{tabular}

\section{Conclusion}

Column and batch adsorption study by using $A$. jiringa seed shells were conducted to identify the use of $A$. jiringa as a natural adsorbent. Parameters such as $\mathrm{pH}$, contact time, adsorbent dosage, temperature and ionic strength were also obtained. Langmuir and Freundlich models were used in this study but eventually Langmuir model was the most suitable model in this study due to the higher $\mathrm{R}^{2}$ obtained: 0.9999 . This showed that the adsorption process undergone by the methylene blue towards the $A$. jiringa shells was more on monolayer adsorption. After applying adsorption kinetic models such as the pseudo first order kinetic, pseudo second order kinetic, Elovich and intra particle, the highest suitability was found out to be the pseudo second order kinetic model. Overall, this indicated that the adsorption was controlled by the chemical adsorption process. Besides that, column adsorption at multiple flow rates was conducted to identify the breakthrough curve time for each flow rate. The rate of methylene blue removed in column adsorption depended on the effluent flow rate. In this study, breakthrough time was faster at higher flow rate which explained the shorter time for natural adsorbent to become saturated. Thomas, Yoon and Nelson and Adam Bohart models were used to describe the column adsorption kinetics. Thomas and Yoon and Nelson's models were identified as the most suitable model to explain the column adsorption kinetics in this study due to the higher 
regression value compared to Adam Bohart model, in between 0.7486 and 0.9527 for Thomas model and in between 0.7486 and 0.9527 for Yoon and Nelson model. Temperature factor affected the uptake of dye and endothermic reaction was determined from the experiment in this study. Then, ionic strength heavily influenced the adsorption capacity of dye waste where an increase in salt concentration will hinder the adsorption between the adsorbent and adsorbate.

\section{Acknowledgements}

The authors gratefully acknowledge Universiti Kebangsaan Malaysia for supporting this research (GUP-2019-042).

\section{Conflicts of Interest}

The authors declare no conflicts of interest regarding the publication of this paper.

\section{References}

Aksu, Z., \& Gönen, F. (2004). Biosorption of Phenol by Immobilized Activated Sludge on a Continuous Packed Bed: Prediction of Breakthrough Curves. Process Biochemistry, 39, 599-613. https://doi.org/10.1016/S0032-9592(03)00132-8

Al Husseiny, H. A. (2014). Adsorption of Methylene blue Dye Using Low Cost Adsorbent of Sawdust: Batch and Continuous Study. Journal of Babylon University, 2, 296-310.

Al-Baidhany, J. H., \& Al-Salihy, S. T. (2016). Removal of Methylene Blue Dye from Aqueous Solution by Using Commercial Granular Activated Carbon with Different Types of Adsorbers. Mesopotamia Environment Journal, 2, 1-11.

Alzaydien, A. S. (2009). Adsorption of Methylene Blue from Aqueous Solution onto a Low-Cost Natural Jordanian Tripoli. American Journal of Environmental Sciences, 5, 197-208.

Ansari, R., \& Mosayebzadeh, Z. (2010). Removal of Basic Dye Methylene Blue from Aqueous Solutions Using Sawdust and Sawdust Coated with Polypyrrole. Journal of the Iranian Chemical Society, 7, 339-350. https://doi.org/10.1007/BF03246019

Auta, M. (2012). Fixed Bed Adsorption Studies of Rhodamine $b$ Dye Using Oil Palm Empty Fruits Bunch Activated Carbon. Journal of Engineering Research and Studies, 3, 3-6.

Azraa, A., Jain, K., Suan, T. K., Rozaini Che, A., \& Seey, T. L. (2012). Equilibrium, Kinetic and Thermodynamic Studies on the Adsorption of Direct Dye onto a Novel Green Adsorbent Developed from Uncaria Gambir Extract. Journal of Physical Science, 23, $1-13$.

Benaïssa, H. (2009). Effect of Temperature on Methylene Blue Sorption from Aqueous Solutions by Almond Peel: Experimental Studies and Modelling (pp. 377-393). Thirteenth International Water Technology Conference.

Bharathi, K. S., \& Ramesh, S. T. (2013). Removal of Dyes Using Agricultural Waste as Low-Cost Adsorbents: A Review. Applied Water Science, 3, 773-790.

https://doi.org/10.1007/s13201-013-0117-y

Boumediene, M., Benaïssa, H., George, B., St. Molina, \& Merlin, A. (2018). Effects of pH and Ionic Strength on Methylene Blue Removal from Synthetic Aqueous Solutions by Sorption onto Orange Peel and Desorption Study. Journal of Materials and Environmental Sciences, 9, 1700-1711. 
Dharmendra, \& Rasma, K. (2015). Dye Removal on Low Cost Adsorbent Media Developed from Pine Cone. Discovery, 40, 190-200.

Dutta, S., Bhattacharyya, A., Ganguly, A., Gupta, S., \& Basu, S. (2011). Application of Response Surface Methodology for Preparation of Low-Cost Adsorbent from Citrus Fruit Peel and for Removal of Methylene Blue. Desalination, 275, 26-36.

https://doi.org/10.1016/j.desal.2011.02.057

Elass, K., Laachach, A., Alaoui, A., \& Azzi, M. (2010). Removal of Methylene Blue from Aqueous Solution Using Ghassoul, a Low-Cost Adsorbent. Applied Ecology and Environmental Research, 8, 153-163. https://doi.org/10.15666/aeer/0802_153163

Fatiha, M., \& Belkacem, B. (2016). Adsorption of Methylene Blue from Aqueous Solutions Using Natural Clay. Journal of Materials and Environmental Science, 7, 285-292.

Goswami, A. K., Kulkarni, S. J., Dharmadhikari, S. K., \& Patil, P. E. (2014). Fly Ash as Low-Cost Adsorbent to Remove Dyes. International Journal of Scientific Research and Management, 2, 842-845.

Gottipati, R., \& Mishra, S. (2010). Application of Biowaste (Waste Generated in Biodiesel Plant) as an Adsorbent for The Removal of Hazardous Dye-Methylene Blue-From Aqueous Phase. Brazilian Journal of Chemical Engineering, 27, 357-367. https://doi.org/10.1590/S0104-66322010000200014

Habib, A., Islam, N., Islam, A., \& Shafiqul Alam, A. (2007). Removal of Copper from Aqueous Solution Using Orange Peel, Sawdust and Bagasse. Pakistan Journal of Analytical \& Environmental Chemistry, 8, 21-25.

Halim, A. A., Abidin, N. N. Z., Awang, N., Ithnin, A., Othman, M. S., \& Wahab, M. I. (2011). Ammonia and COD Removal from Synthetic Leachate Using Rice Husk Composite Adsorbent. Journal of Urban and Environmental Engineering, 5, 24-31.

Halim, A. A., Aziz, H. A., Joharia, M. A. M., Ariffin, K. S., \& Adlan, M. N. (2010). Ammoniacal Nitrogen and COD Removal from Semi-Aerobic Landfill Leachate Usinga Composite Adsorbent: Fixed Bed Column Adsorption Performance. Journal of Hazardous Materials, 175, 960-964. https://doi.org/10.1016/j.jhazmat.2009.10.103

Halim, A. A., Ezani, E., Othman, M. S., Awang, N., Wahab, M. I., \& Ithnin, A. (2012). Adsorption Study of Aluminium onto Curcuma Longa. Nature Environment and PolIution Technology, 11, 193-197.

Halim, A. A., Kee, K. H., \& Hanafiah, M. M. (2015). Removal of Methylene Blue from Dye Wastewater Using River Sand by Adsorption. Nature Environment and Pollution Technology, 14, 89-94.

Han, R., Wang, Y., Zhao, X., Wang, Y., Xie, F., Cheng, J., \& Tang, M. (2009). Adsorption of Methylene Blue by Phoenix Tree Leaf Powder in a Fixed-Bed Column: Experiments and Prediction of Breakthrough Curves. Desalination, 245, 284-297.

https://doi.org/10.1016/j.desal.2008.07.013

Janet, A., Kumaresan, R., \& Maheshwari, S. U. (2015). Removal of Dyes in Adsorption Column. Journal of Chemical and Pharmaceutical Research, 7, 1718-1723.

Kanawade, S. M., \& Gaikwad, R. W. (2011). Removal of Methylene Blue from Effluent by Using Activated Carbon and Water Hyacinth as Adsorbent. International Journal of Chemical Engineering and Applications, 2, 317-319.

https://doi.org/10.7763/IJCEA.2011.V2.126

Khan, A. R., Tahir, H., Uddin, F., \& Hameed, U. (2005). Adsorption of Methylene Blue from Aqueous Solution on The Surface of Wool Fiber and Cotton Fiber. Journal of Applied Sciences and Environmental Management, 9, 29-35.

https://doi.org/10.4314/jasem.v9i2.17287

Lei, G., Wei, S., \& Lingying, K. (2013). Adsorption of Methylene Blue by NaOH-Modified 
Dead Leaves of Plane Trees. Computational Water, Energy and Environmental Engineering, 2, 13-19. https://doi.org/10.4236/cweee.2013.22B003

Mathivanan, M., \& Saranathan, E. S. (2015). Sugarcane Bagasse-A Low Cost Adsorbent for Removal of Methylene Blue Dye from Aqueous Solution. Journal of Chemical and Pharmaceutical Research, 7, 817-822.

Mohammed, M. A., Shitu, A., \& Ibrahim, A. (2014). Removal of Methylene Blue Using Low Cost Adsorbent: A Review. Research Journal of Chemical Sciences, 4, 91-102.

Moubarak, F., Atmani, R., Maghri, I., Elkouali, M., Talbi, M., Bouamrani, M. L., Salouhi, M., \& Kenz, A. (2014). Elimination of Methylene Blue Dye with Natural Adsorbent (Banana Peels Powder). Global Journal of Science Frontier Research: B, 14, 38-44.

Mulugeta, M., \& Lelisa, B. (2014). Removal of Methylene Blue (Mb) Dye from Aqueous Solution by Bioadsorption onto Untreated Parthenium hystrophorous Weed. Modern Chemappl, 2, 1-5.

Muslim, A., Ellysa, E., \& Said, S. D. (2017). Cu(II) Ion Adsorption Using Activated Carbon Prepared from Pithecellobium jiringa (Jengkol) Shells with Ultrasonic Assistance: Isotherm, Kinetic and Thermodynamic Studies. Journal of Engineering and Technological Sciences, 49, 472-490. https://doi.org/10.5614/j.eng.technol.sci.2017.49.4.4

Oladoja, N. A., Aboluwoye, C. O., \& Oladimeji, Y. B. (2008). Kinetics and Isotherm Studies on Methylene Blue Adsorption onto Ground Palm Kernel Coat. Turkish Journal of Engineering and Environmental Sciences, 32, 303-312.

Oyelude, E. O., \& Appiah-Takyi, F. (2012). Removal of Methylene Blue from Aqueous Solution Using Alkali-Modified Malted Sorghum Mash. Turkish Journal of Engineering and Environmental Sciences, 36, 161-169.

Pamukoglu, M. Y., Kirkan, B., \& Senyurt, M. (2017). Removal of Thorium (IV) from Aqueous Solution by Biosorption onto Modified Powdered Waste Sludge: Experimental Design Approach. Journal of Radioanalytical and Nuclear Chemistry, 314, 343-352.

Patil, S., Renukdas, S., \& Patel, N. (2011). Removal of Methylene Blue, A Basic Dye from Aqueous Solutions by Adsorption Using Teak Tree (Tectona grandis) Bark Powder. International Journal of Environmental Sciences, 1, 711-726.

Priyantha, N., Lim, L. B. L., \& Dahri, M. K. (2015). Dragon Fruit Shells as a Potential Biosorbent for the Removal of Methylene Blue Dye from Aqueous Solution. International Food Research Journal, 22, 2141-2148.

Sekhula, M. M., Okonkwo, J. O., Zvinowanda, C. M., Agyei, N. N., \& Chaudhary, A. J. (2012). Fixed Bed Column Adsorption of Cu(II) onto Maize Tassel-PVA Beads. Journal of Chemical Engineering \& Process Technology, 3, 1-5.

https://doi.org/10.4172/2157-7048.1000131

Shahryari, Z., Goharrizi, A. S., \& Azadi, M. (2010). Experimental Study of Methylene Blue Adsorption from Aqueous Solutions onto Carbon Nano Tubes. International Journal of Water Resources and Environmental Engineering, 2, 16-28.

Shehata, A. M. A. (2013). Removal of Methylene Blue Dye from Aqueous Solutions by Using Treated Animal Bone as a Cheap Natural Adsorbent. International Journal of Emerging Technology and Advanced Engineering, 3, 507-513.

Slimani, R., Anouzla, A., Abrouki, Y., Ramli, Y., El Antri, S., Mamouni, R., Lazar, S., \& El Haddad, M. (2011). Removal of a Cationic Dye-Methylene Blue-from Aqueous Media by the Use of Animal Bone Meal as a New Low Cost Adsorbent. Journal of Materials and Environmental Science, 2, 77-87.

Sodeinde, O., \& Eboreime, U. (2013). Adsorption of Textile Wastes Containing Methylene Blue, \& Congo Red Using Activated Carbon Produced from Coconut Shells. International Journal of Computational Engineering, \& Management, 16, 21-26. 
Sulyman, M. (2014). Fixed-Bed Column Packed with Low-Cost Spent Tea Leaves for The Removal of Crystal Violet from Aqueous Solution. Proceedings of 5th International Conference on Environmental Science and Technology, 69, 10-118.

Suteu, D., \& Malutan, T. (2013). Industrial Cellolignin Wastes as Adsorbent for Removal of Methylene Blue Dye from Aqueous Solutions. BioResources, 8, 427-446. https://doi.org/10.15376/biores.8.1.427-446

Tamilselvi, S., \& Asaithambi, M. (2015). Column Mode Adsorption Studies of Acid Dye Using A Novel Adsorbent. Rasayan Journal of Chemistry, 8, 84-91.

Tsai, W. T., Chen, H. R., Kuo, K. C., Lai, C. Y., Su, T. C., Chang, Y. M., \& Yang, J. M. (2009). The Adsorption of Methylene Blue from Aqueous Solution Using Waste Aquacultural Shells Powders. Environmental Engineering and Management Journal, 19, 165-172.

Uddin, L. Q., Kelly, A. M., Biswal, B. B., Castellanos, F. X., \& Milham, M. P. (2009). Functional Connectivity of Default Mode Network Components: Correlation, Anticorrelation and Causality. Human Brain Mapping, 30, 625-637.

https://doi.org/10.1002/hbm.20531

Velmurugan, P., Kumar, V. R., \& Dhinakaran, G. (2011). Dye Removal from Aqueous Solution Using Low Cost Adsorbent. International Journal of Environmental Sciences, 1, 1492-1503. 